\title{
Use of a Spacing Method Before Sterilization Among Couplesin Kerala, India
}

By Francis Zavier and Sabu S. Padmadas

Context: Many couples in India never use a reversible method to delay or space births, and instead adopt sterilization as their first and only method. Little is known about the factors that distinguish sterilized couples who have used spacing methods from those who go directly to using a permanent method.

Methods: Data on 2,029 ever-married women protected by sterilization are taken from the part of the 1992-1993 Indian National Family Health Survey that was conducted in the state of Kerala. Multivariate logistic regression techniques are used to assess the socioeconomic, demographic and behavioral characteristics that determine prior temporary method use among sterilized couples.

Results: Once all significant variables are controlled for, higher educational attainment (of either partner) independently increases the likelihood that a couple will have used a method to delay or space births, as does middle socioeconomic status. That likelihood is also significantly higher among respondents who experienced an abortion, among Christian women and among those who were older than age 25 when either they or their partner were sterilized. However, the likelihood of temporary method use before sterilization is significantly reduced among respondents who preferred shorter birth intervals and among relatively older women (age 31 and older). The median interval between the first and second children born to sterilized couples who had ever used a reversible method was longer than that among children born to couples who had relied only on sterilization (32 months vs. 26 months).

Conclusions: In Kerala, both small family size ideals and a desire to shorten the period of exposure to the risk of pregnancy might explain the tendency for couples to go directly to sterilization at a relatively young age and bypass temporary method use altogether. An approach that emphasizes clients' choice of methods and high-quality services that cater to their needs would enhance the use of methods to space births.

International Family Planning Perspectives, 2000, 26(1):29-35

$\mathrm{O}$ ne of the principal objectives of family planning programs, as endorsed by Programme of Action adopted in Cairo at the 1994 International Conference on Population and Development, is to enable couples to decide freely the number, timing and spacing of their births; to ensure that they make informed choices; and to make available a full range of safe and effective methods. ${ }^{1}$ Of this range of methods, however, sterilization (mainly female sterilization) is the most commonly used method, especially in developing countries. ${ }^{2}$ When couples achieve their desired family size, most choose to undergo sterilization, since it is considered the most effective and safest method to stop childbearing. In some countries where the use of modern contraceptive methods is uncommon, sterilization is often the first and sole method of family planning that

*In 1966-1967, to meet demographic goals, the Indian government introduced targets for numbers of contraceptive acceptors, and health workers in primary health centers at the district and state levels were assigned targets to fulfill for sterilization and other methods. couples use to control their family size. ${ }^{3}$

In India, people often equate the term family planning with sterilization, although government policies aim to promote the use of reversible methods. ${ }^{4} \mathrm{Sev}-$ eral factors account for sterilization's widespread use in India. Government incentives offered both to potential users and to providers throughout the late 1960s and the $1970 \mathrm{~s}^{*}$ undoubtedly contributed to the predominance of permanent methods over temporary methods.

In response to the Cairo recommendations and to the results of internal evaluations, and because of reports that the program was administered unscrupulously and that the numbers of acceptors were inflated, the Indian government introduced a target-free approach in April 1996. Under the new target-free philosophy, grassroots health workers are charged with offering family planning services to couples who are interested both in spacing their children and in limiting family size.

Nevertheless, use of reversible methods remains comparatively poor. For example, as of March 1995, temporary methods accounted for just $35 \%$ of all method use in India. ${ }^{5}$ (Moreover, only $3 \%$ of couples relied on condoms in 1992-1993, ${ }^{6}$ an alarming fact given the rapidly increasing rates of HIV and other reproductive tract infections in India.) Such limited reliance on spacing methods increases the risk of relatively short birth intervals, which in turn increase the risk of premature delivery and of low birth weight. ${ }^{7}$ In addition, rates of infant and child mortality, particularly neonatal mortality, are higher among children born after short birth intervals. ${ }^{8}$ The health of both the mother and the child is enhanced with adequate birthspacing intervals, whether they are achieved through natural postpartum infecundability, through prolonging that period through breastfeeding or through the effective use of spacing methods.

At the national level, the 1992-1993 National Family Health Survey (NFHS) indicated that $31 \%$ of couples of reproductive age were protected by sterilization, and that among these couples, only $22 \%$ had ever used a reversible method before the operation. ${ }^{9}$ The use of spacing methods prior to sterilization varies widely by state, however, ranging from a low of $7 \%$ among sterilized couples in Andhra Pradesh, to $39 \%$ and $43 \%$ in Kerala and West Bengal, respectively, and to a high of $56 \%$ in Assam (see Table 1, page 30).

This wide variation by state reflects India's enormous socioeconomic, demographic, geographic and cultural diversity. The low use of temporary methods in the majority of Indian states may be attributable to a lack of knowledge about and access to such methods. ${ }^{10}$ In addition, a strong preference among couples for sterilization as soon as they achieve their desired family size might shorten the period of reproductive exposure, thereby lowering the likelihood of spacing method

Francis Zavier is doctoral research fellow at the Department of Demography, University of Kerala, Trivandrum, India. Sabu S. Padmadas is doctoral research fellow, Population Research Center, Faculty of Spatial Sciences, University of Groningen, The Netherlands. The authors would like to thank P.S. Nair and Sukumari N. Nair for their helpful comments and encouragement during the course of analysis and writing. 
Table 1. Among married women of reproductive age who are protected by sterilization, percentage who have ever used a temporary method of contraception, by selected states, India,1992-1993

\begin{tabular}{lr}
\hline State & $\%$ \\
\hline India & $\mathbf{2 1 . 9}$ \\
North & \\
Assam & 55.8 \\
Haryana & 24.9 \\
Himachal Pradesh & 36.1 \\
Punjab & 26.6 \\
Rajasthan & 8.6 \\
Central & \\
Madhya Pradesh & \\
Uttar Pradesh & 12.8 \\
& 13.4 \\
East & \\
Bihar & \\
Orissa & 9.5 \\
West Bengal & 12.7 \\
West & 42.6 \\
Gujarat & \\
Maharashtra & 13.9 \\
South & 12.9 \\
Andhra Pradesh & \\
Karnataka & \\
Kerala & 6.8 \\
Tamil Nadu & 16.7 \\
\hline & 38.6 \\
Source Conp & 18.2 \\
\hline
\end{tabular}

Source: Computed from the raw data files of the 1992-1993 National Family Health Survey (MCH and Family Planning), India.

use. Son preference and the desire for a family of at least three children have also influenced the sterilization rate in India. ${ }^{11}$ Further, India's family planning program has largely failed to encourage the use of reversible methods, particularly among young women (those aged 15-30) who are in the most fertile years of their reproductive period. ${ }^{12}$

Attempts to promote increased reliance on temporary methods could benefit from data on what distinguishes women who use other methods before sterilization from those who never use any method but a permanent one. We chose to study contraceptive behavior among women in one especially developed Indian state, Kerala.

The southwestern state of Kerala has already completed the last stage of its demographic transition: Among India's 25 states, Kerala holds the unique distinction of having demographic indicators that closely re-

*The nationwide and individual-state versions of the NFHS were initiated by the Ministry of Health and Family Welfare, Government of India, and were coordinated by the International Institute for Population Sciences, Mumbai.

tRespondents mentioned having used a total of six family planning methods overall, with many women citing experience with more than one method. For example, $46 \%$ of the 783 women who had ever tried a spacing method had practiced rhythm, $41 \%$ had relied on withdrawal, $38 \%$ on condoms, $21 \%$ on the IUD, $12 \%$ on the semble those of a developed country. ${ }^{13}$ As of 1992-1993, it had achieved a total fertility rate of 2.0 lifetime births per woman, a low infant mortality rate of $17 \mathrm{infant}$ deaths per 1,000 live births, a sex ratio of 1,036 females per 1,000 males, and a female literacy rate of $86 \%$ (according to the 1991 census). ${ }^{14}$ Moreover, official government data indicate that in 1990-1991, Kerala had the highest level of overall contraceptive use of any state $-60 \%$ of couples, compared with $44 \%$ for the country as a whole. ${ }^{15}$

Nonetheless, Kerala also follows the national pattern of comparatively little reliance on reversible methods. The 19921993 NFHS indicated that in Kerala, fewer than two-fifths of couples protected by sterilization had ever used a spacing method. ${ }^{16}$ Another study, conducted in Kerala in 1992, put this proportion at only $20 \% .{ }^{17}$ Thus, in this context, we assess the socioeconomic, demographic and behavioral characteristics that either motivate or inhibit couples from practicing contraception to delay or space births before they ultimately adopt sterilization.

\section{Data and Methodology}

The Kerala data come from the NFHS* conducted in the state from October 1992 to February 1993. That survey collected individual-level data on 4,332 ever-married women aged 13-49, based on representative samples from 4,387 households. Nearly one-half of these women- $47 \%$ or 2,029 women-were protected by either their own or their partner's sterilization; these women form our study population.

The NFHS asked women about any contraceptive used by themselves or by their partners. Although many women reported having used more than one reversible method, we were concerned with ever-use only. ${ }^{\dagger}$ We conducted multivariate logistic regression analyses to uncover the factors that determined the likelihood that couples had ever used a temporary method before sterilization. We chose explanatory variables based on an extensive review of the literature. These included eight demographic and socioeconomic variablesthe respondent's age, her place of resi-

pill and fewer than $1 \%$ on an injectable contraceptive.

$\ddagger$ This is a composite index, based on NFHS data, that measured the availability of household amenities. Weights were assigned according to the amenity's economic value and importance. The index reflected commodities such as a flush toilet, lighting, a separate kitchen, the number of rooms, type of cooking fuel, structure of the house, source of drinking water, the presence of livestock and ownership of consumer durables (including television, video cassette recorder, scooter, car, bicycle, clock or sewing machine, among others). Households dence, her and her husband's educational attainment, her religion, her standard of living ${ }^{18}$ (as measured by a Standard of Living Index $\ddagger$ ), her exposure to the mass media and her employment status at the time of the interview.

We also examined eight reproductive behavior and attitude variables, such as the respondent's experience of abortion, $\$$ the source of sterilization, her age at the time of tubal ligation or vasectomy, whether she regretted the sterilization, her approval of family planning, her ideal birth interval, her ideal family size and the number of children ever born. (We excluded a variable on knowledge of family planning, because knowledge of at least one method is almost universal in Kerala. ${ }^{19}$ )

We created three separate logistic regression models to analyze the effects of the significant variables (based on chisquare tests) on the likelihood of ever using a reversible contraceptive before sterilization. The first controlled for the woman's demographic and socioeconomic characteristics only, the second controlled for the woman's reproductive behavior and attitudes only (along with age, which was controlled for in all three models), and the third considered all of the variables that were significant in the first two models.

We also used NFHS data to examine how ever-use of a temporary method affected the length of birth intervals among Kerala women protected by sterilization.

\section{Results \\ Sample Characteristics}

Overall, the women in the sample were predominantly Hindu (64\%), lived in rural areas $(71 \%)$, did not work outside the home $(67 \%)$ and were moderately well educated $(23 \%$ had attended middle school and $15 \%$ had attended high school, see Table 2). Thirty-eight percent of the couples had elected to be sterilized once they had had two children, an additional 34\% did so after having had three children, $13 \%$ did so after four children and $14 \%$ did so after having five or more. Most of these women $(61 \%)$ had never used any method other than sterilization (not shown).

were classified into three groups based on their standard of living score - either low (0-9), medium (10-19) or high (20 or more). As the standard of living score is based on respondents' possession of consumer durable goods and other household amenities, a high score reflects consumer behavior more than overall economic levels in the state.

$\S$ We made no distinction between induced and spontaneous abortion, but many women who reported having had a spontaneous abortion probably had had an induced abortion and were reluctant to report it as such. 


\section{Bivariate Analyses}

About $39 \%$ of couples had used some reversible method before sterilization, with no significant difference between urban and rural women (Table 3, page 32). Everuse of a spacing method did vary significantly by the seven remaining socioeconomic characteristics, however. For example, respondents aged 30 and younger were significantly more likely than older women to have ever used a method other than sterilization. Spacing method use also rose steadily with increasing education (of either partner), as $66 \%$ of women who had completed high school had ever used a temporary method, compared with $24 \%$ of women who had had no schooling. Only $26 \%$ of Muslim women had ever used a reversible method, compared with $39 \%$ of Hindu women and $47 \%$ of Christian women. The tendency to have used a spacing method before sterilization also increased with the standard of living score and with exposure to the media. However, the proportion with experience using a reversible method was significantly lower among women who were working at the time of the survey than among those who were not.

Ever-use of a spacing method varied significantly by each of the eight reproductive behavior variables, except for regret over sterilization. For example, women who had had an induced abortion or miscarriage were more likely than those who had not to have used a reversible method. Ever-use of a spacing method was also significantly higher among those who relied on the private sector than among those who used the public sector for their sterilization, and among women who were comparatively older at the time of their or their partner's sterilization.

Ever-use of a spacing method was significantly higher among women who said they approved of family planning than among those who said they did not. As expected, women who considered birth intervals of more than 24 months to be ideal were significantly more likely than those who preferred shorter intervals to have ever used a reversible method. Moreover, the proportion who had used a temporary method was significantly higher among women whose ideal family size consisted of two children or fewer than among those who viewed families of more than two to be ideal. Previous use of temporary methods decreased with increasing number of children ever born.

We also observed a difference in the length of birth intervals between users and nonusers of a reversible method before ster- ilization (Table 4, page 32). For example, intervals between first and second births were six months longer among couples who had ever used a spacing method than among those who had not (median lengths of 32 months and 26 months, respectively). This difference narrowed to only two months, however, when we compared the second-birth intervals among users and nonusers of a reversible method before sterilization (median lengths of 29 months and 27 months, respectively).

Moreover, among women with two children, only $28 \%$ of those who had ever used a reversible method before sterilization had a birth fewer than 24 months after a first child, compared with $40 \%$ among women who had never used a temporary method.

Multivariate Analyses In the first of the three multivariate logistic analyses, which controlled for the socioeconomic variables and age only, both the husband's and the wife's educational attainment were significantly associated with the use of spacing methods before sterilization (Table 5, page 33). For example, respondents who had completed middle school were twice as likely (odds ratio of 2.1), and high school-educated women were 3.7 times as likely, to have practiced contraception before adopting sterilization as were those who had had no schooling. There was no significant difference in that likelihood, however, when women with primary schooling were compared with women who had never been to school. The husband's education had similar independent effects on the likelihood of temporary method use, although the magnitude of the resulting odds ratios was lower.

Once all the socioeconomic variables were controlled for, Christian women were 1.4 times as likely as Hindu women to have ever used a method other than sterilization.
There were no significant differences, however, between Hindu and Muslim women.

Women whose standard of living index was in the medium range were about $50 \%$ more likely than those who scored low on that index to have ever used a temporary method. There was no significant difference in that likelihood between women with a high standard of living index score and those with a low one.

Women who were older than age 30 were $25 \%$ less likely to have used a method before sterilization than were younger women. Women's employment status and their exposure to the media had no independent effect on the likelihood of temporary method use.

Once the effects of age and reproductive attitudes and behavior variables were controlled for, women who had ever had an abortion were significantly more likely to 
Table 3. Percentage of ever-married women protected by sterilization who ever used a reversible method of contraception, by demographic and socioeconomic characteristics and reproductive attitudes and behaviors

\begin{tabular}{lc}
\hline Characteristic, attitude or behavior & $\%$ \\
\hline All women & $\mathbf{3 8 . 6}$ \\
Age $^{\star \star}$ & \\
$\leq 30$ & 44.6 \\
$>30$ & 36.9
\end{tabular}

Place of residence
Urban

Urban

36.2

39.6

Respondent's education ${ }^{\star \star \star}$

None

Primary school

Middle school

zhigh school

Husband's education***

None

Primary school

Middle school

zhigh school

Religion $^{\star * \star}$

Hindu

Muslim

Christian

20.4

27.4

35.4

53.0

Standard of living index ${ }^{\star \star \star}$

Low

Medium

High

Exposed to mass media ${ }^{\star \star \star}$

Yes

No

41.9

34.4

Currently employed ${ }^{\star}$

Yes

No

Ever had abortion or miscarriage $\mathrm{e}^{\star \star *}$ Yes

No

Source of sterilization ${ }^{\star \star \star}$

Private sector

Public sector

Respondent's age at own

or partner's sterilization ${ }^{\star \star \star}$

$<25$

$25-29$

$\geq 30$

35.5

40.2

51.7

35.7

49.1

36.5

33.9

40.8

45.0

Respondent regrets sterilization

Yes

No

41.0

39.0

Respondent approves of family planning ${ }^{\star \star *}$ Yes

No

40.0

27.0

Ideal birth interval ${ }^{\star \star *}$

$\leq 24$ months

$>24$ months

25.3

41.8

Ideal family size $\mathrm{e}^{\star \star \star}$

$\leq 2$ children

$>2$ children

No. of children ever born at time of sterilization ${ }^{\star * *}$ $\leq 2$

$>2$

${ }^{*} p<.05 .{ }^{* *} p<.01{ }^{* \star *} p<.001$. Note: See previous table on the number of missing cases for eight variables. have used a method prior to sterilization than were those who had not undergone an abortion (odds ratio of 1.8). $\mathrm{A}$ few other variables-approving of family planning and being 25 or older* at the time of the sterilization-also independently raised the likelihood of using a method before sterilization.

Other variables, however, significantly decreased the likelihood of reversible method use in the second model. For example, women older than 30 at the time of the interview were about $40 \%$ less likely to be users than those aged 30 and younger. Moreover, couples who opted for a public-sector source of sterilization services were $37 \%$ less likely to have used a spacing method than were those who relied on a private provider. Women who considered a birth interval of 24 months or shorter to be ideal were $47 \%$ less likely than those whose ideal interval was more than 24 months to have used a method; and those believing that more than two children would be ideal were $29 \%$ less likely. Finally, although women who had had at least two children before adopting sterilization were somewhat less likely to have ever used a reversible method, this association was not statistically significant.

The variables that proved significant in either of the first two models (with age being significant in both) were then entered into a third model that controlled for all 11 significant variables simultaneously. In this final model, all variables except ideal family size and source of sterilization retained their significance. The effect of the respondent's current age retained its significance in all three of the models.

\section{Discussion and Conclusions}

In Kerala, several factors play an important role in a couple's decision to avoid using spacing methods and go directly to relying on a permanent method. It seems that if couples intend to become sterilized, they do not bother using methods to space their children.

The finding that better-educated men and women are significantly more likely than their less-educated peers to have used a reversible method corroborates data from earlier studies in India and in other countries, which found lower levels of temporary method use and of contraceptive knowledge among sterilized women with comparatively less schooling. ${ }^{20}$

Schooling imparts accurate knowledge about birthspacing and the need to use spacing methods; thus, even if less-educated persons are aware that such methods exist, they may be inadequately informed about them or may be reluctant to use them out of fear of side effects, perceived inaccessibility or opposition by a spouse or other relative. Ignorance of the range of temporary methods available might also prompt couples to forgo their use. ${ }^{21}$ Educated persons may also communicate and demand family planning services more easily than noneducated persons. Reliance on reversible methods could increase if health workers at the grassroots level were to disseminate more information about them.

In the state of Kerala, Christians are more likely than those of other religions to practice family planning before becoming sterilized; this finding reflects Christians' overall higher levels of method use in the state. ${ }^{22}$ However, even Muslim women in Kerala have relatively high levels of contraceptive use, compared with Muslim women in other states. ${ }^{23}$

Our analysis also uncovered another important association-the reduced likelihood of early use of reversible methods among sterilized couples who scored low on the standard of living index. This finding might lead one to ask whether couples

*Note that cases are necessarily censored here, because persons who are younger than age 30 could not have been sterilized at age 30 or older. 
with a low standard of living choose sterilization over a reversible method because of incentives or pressure from health workers. Although studies have not yet validated this hypothesis, ${ }^{24}$ research has shown that economic incentives triggered a demand for sterilization in Kerala. ${ }^{25}$

The age at which couples choose to undergo sterilization is mediated through their knowledge of the procedure and their desire to stop childbearing, together with the motivating efforts of health workers. The recent trend toward adoption of sterilization at progressively younger ages reflects small family-size ideals and a desire for shorter periods of exposure to the risk of unwanted childbearing, once couples achieve their desired family size of two children. ${ }^{26} \mathrm{How}$ ever, such sole reliance on sterilization might result in shorter birth intervals. Indeed, we found that couples who had relied solely on sterilization had shorter birth intervals than those who had ever used a method other than sterilization (i.e., a median interval between first and second births of 26 months versus one of 32 months).

We also found that, in the analysis that controlled for reproductive attitudes and behavior only, the likelihood of using a spacing method was lower among respondents who obtained their sterilization through the public sector. In India, the private sector is known to deliver higher quality services than the public sector, which suffers problems of distribution and supply. ${ }^{27}$ However, this problem is less severe in Kerala than in the rest of the country, because of that state's comparatively better transportation networks and communication facilities. $^{28}$

This study also revealed that respondents who had experienced an induced or spontaneous abortion were more likely than those who had not to have used a spacing method. Women who have had an abortion might be more motivated than others to defer subsequent births and be more likely to visit health clinics, where they would learn about spacing methods..$^{29}$ Moreover, women who had had an abortion might even have considered the abortion itself as a method of birth spacing. An earlier study pointed out that the high demand for abortion services in India reflects a high unmet need for spacing methods in that country. ${ }^{30}$ However, this unmet need is probably not as strong in Kerala as in the rest of India, since that state has a relatively high rate of health institution utilization. ${ }^{31}$

The overall poor performance of India's family planning program, coupled with people's perceptions that the quality of care is substandard, ${ }^{32}$ could explain the
Table 5. Results of multivariate logistic regression analyses predicting the likelihood of ever having used a temporary method before adopting sterilization, by type of variable controlled for in the analysis $(\mathrm{N}=2,029)$

\begin{tabular}{|c|c|c|c|c|c|c|}
\hline \multirow[t]{2}{*}{ Variable } & \multicolumn{2}{|c|}{$\begin{array}{l}\text { Adjusted for socio- } \\
\text { economic variables only }\end{array}$} & \multicolumn{2}{|c|}{$\begin{array}{l}\text { Adjusted for reproductive } \\
\text { attitudes and behavior only }\end{array}$} & \multicolumn{2}{|c|}{$\begin{array}{l}\text { Adjusted for all } \\
\text { significant variables }\end{array}$} \\
\hline & Coefficient & Odds ratio & Coefficient & Odds ratio & Coefficient & Odds ratio \\
\hline \multicolumn{7}{|l|}{ Age } \\
\hline$\leq 30$ & 0.000 & 1.00 & 0.000 & 1.00 & 0.000 & 1.00 \\
\hline$>30$ & -0.284 & $0.75^{\star}$ & -0.471 & $0.62^{\star \star \star}$ & -0.493 & $0.61^{\star \star \star}$ \\
\hline \multicolumn{7}{|c|}{ Respondent's education } \\
\hline None & 0.000 & 1.00 & na & na & 0.000 & 1.00 \\
\hline Primary & 0.131 & 1.14 & na & na & 0.133 & 1.14 \\
\hline Middle school & 0.744 & $2.10^{\star \star *}$ & na & na & 0.742 & $2.10^{\star \star \star}$ \\
\hline >high school & 1.307 & $3.70^{\star \star \star}$ & na & na & 1.202 & $3.32^{\star \star \star}$ \\
\hline \multicolumn{7}{|c|}{ Husband's education } \\
\hline None & 0.000 & 1.00 & na & na & 0.000 & 1.00 \\
\hline Primary & 0.280 & 1.32 & na & na & 0.324 & 1.38 \\
\hline Middle school & 0.550 & $1.73^{\star}$ & na & na & 0.586 & $1.79^{*}$ \\
\hline zhigh school & 0.800 & $2.22^{\star * *}$ & na & na & 0.798 & $2.22^{\star *}$ \\
\hline \multicolumn{7}{|l|}{ Religion } \\
\hline Hindu & 0.000 & 1.00 & na & na & 0.000 & 1.00 \\
\hline Muslim & -0.297 & 0.74 & na & na & -0.279 & 0.75 \\
\hline Christian & 0.364 & $1.44^{\star *}$ & na & na & 0.351 & $1.42^{\star *}$ \\
\hline \multicolumn{7}{|c|}{ Standard of living index } \\
\hline Low & 0.000 & 1.00 & na & na & 0.000 & 1.00 \\
\hline Medium & 0.408 & $1.50^{\star}$ & na & na & 0.479 & $1.61^{*}$ \\
\hline High & 0.259 & 1.30 & na & na & 0.250 & 1.28 \\
\hline \multicolumn{7}{|c|}{ Exposed to mass media } \\
\hline Yes & 0.000 & 1.00 & na & na & na & na \\
\hline No & 0.035 & 1.03 & na & na & na & na \\
\hline \multicolumn{7}{|c|}{ Currently employed } \\
\hline Yes & 0.042 & 1.04 & na & na & na & na \\
\hline No & 0.000 & 1.00 & na & na & na & na \\
\hline \multicolumn{7}{|c|}{ Ever had abortion or miscarriage } \\
\hline Yes & na & na & 0.578 & $1.78^{\star \star \star}$ & 0.642 & $1.90^{\star * *}$ \\
\hline No & na & na & 0.000 & 1.00 & 0.000 & 1.00 \\
\hline \multicolumn{7}{|c|}{ Source of sterilization } \\
\hline Private sector & na & na & 0.000 & 1.00 & 0.000 & 1.00 \\
\hline Public sector & na & na & -0.46 & $0.63^{\star * *}$ & -0.060 & 0.94 \\
\hline \multicolumn{7}{|c|}{$\begin{array}{l}\text { Respondent's age at own } \\
\text { or partner's sterilization }\end{array}$} \\
\hline$<25$ & na & na & 0.000 & 1.00 & 0.000 & 1.00 \\
\hline $25-29$ & na & na & 0.420 & $1.52^{\star \star \star}$ & 0.286 & $1.33^{*}$ \\
\hline$\geq 30$ & na & na & 0.721 & $2.05^{\star \star \star}$ & 0.602 & $1.82^{\star \star \star}$ \\
\hline \multicolumn{7}{|c|}{$\begin{array}{l}\text { Respondent approves of } \\
\text { family planning }\end{array}$} \\
\hline Yes & na & na & 0.599 & $1.82^{* *}$ & 0.527 & $1.69^{\star *}$ \\
\hline No & na & na & 0.000 & 1.00 & 0.000 & 1.00 \\
\hline \multicolumn{7}{|c|}{ Ideal birth interval } \\
\hline$\leq 24$ months & na & na & -0.632 & $0.53^{\star \star \star *}$ & -0.516 & $0.59^{* * *}$ \\
\hline$>24$ months & na & na & 0.000 & 1.00 & 0.000 & 1.00 \\
\hline \multicolumn{7}{|l|}{ Ideal family size } \\
\hline$\leq 2$ children & na & na & 0.000 & 1.00 & 0.000 & 1.00 \\
\hline$>2$ children & na & na & -0.328 & $0.71^{\star \star}$ & -0.088 & 0.91 \\
\hline \multicolumn{7}{|c|}{$\begin{array}{l}\text { No. of children ever born at time } \\
\text { of sterilization }\end{array}$} \\
\hline$\leq 2$ & na & na & 0.000 & 1.00 & na & na \\
\hline$>2$ & na & na & -0.175 & 0.83 & na & na \\
\hline Constant & $-1.565^{\star * *}$ & & $-0.338^{* * *}$ & & $-2.069^{* * *}$ & \\
\hline-2 log likelihood & $2,478.4$ & & $2,400.5$ & & $2,256.9$ & \\
\hline$\chi^{2}$ & $221.06^{* * *}$ & & $140.95^{\star * *}$ & & $283.76^{* * *}$ & \\
\hline$d f$ & 13 & & 9 & & 18 & \\
\hline
\end{tabular}

${ }^{*} \mathrm{p}<.05 .{ }^{* *} \mathrm{p}<.01 .{ }^{* * *} \mathrm{p}<.001$. Note: na=not applicable. 
low use of spacing methods before sterilization in Kerala. There is a dire need to reconsider the existing family welfare services in Kerala. The program needs to shift its focus to "choice and service" and to steer clear of coercive approaches-that is, couples should be granted the right to freely decide their choice of method without fear of repercussions.

The predominance of traditional methods among couples who used a method prior to sterilization points to the need to popularize more effective modern methods. Efforts need to be made to expand the range of spacing methods available and to improve the quality of services. Currently, the spacing methods offered mainly through primary health centers include the IUD, the pill and the condom. While such methods are available free of cost at public-sector facilities, users must pay a fee at a private-sector center. We believe that public-sector facilities in Kerala could improve their image and raise the quality of their services by introducing a token or nominal fee.

The recently introduced target-free approach and the new national Reproductive and Child Health Services program may succeed in popularizing spacing methods in Kerala. The success of this new focus and program will be assessed in the forthcoming round of the NFHS surveys in Kerala, as well as in the rest of the states and in India as a whole.

\section{References}

1. Programme of Action of the 1994 International Conference on Population and Development, Chapters I-VIII, Population and Development Review, 1995, 21(1):187-213.

2. Rutenberg N and Landry E, A comparison of sterilization use and demand from the Demographic and Health Surveys, International Family Planning Perspectives, 1993, 19(1):4-13.

3. Ibid.

4. Bose A, India and the Asian Population Perspective, Delhi, India: BR Publishing, 1993.

5. Government of India, Family Welfare Program in India, Yearbook, 1994-1995, New Delhi: Ministry of Health and Family Welfare, Department of Family Welfare, 1996.

6. International Institute for Population Sciences (IIPS), National Family Health Survey (MCH and Family Planning), India, 1992-93, Mumbai: IIPS, 1995.

7. Miller JE, Is the relationship between birth intervals and perinatal mortality spurious? evidence from Hungary and Sweden, Population Studies, 1989, 43(3):479-495; and Gribble JN, Birth intervals, gestational age, and low birth weight: are the relationships confounded? Population Studies, 1993, 47(1):133-146.

8. Miller JE et al, Birth spacing and child mortality in Bangladesh and the Philippines, Demography, 1992, 29(2):305-317; Boerma JT and Bicego GT, Preceding birth intervals and child survival: searching for pathways of influence, Studies in Family Planning, 1992, 23(4):243-256; and Hobcraft JN, McDonald JW and Rutstein SO, De- mographic determinants of infant and early child mortality: a comparative analysis, Population Studies, 1985, 39(3):363-385.

9. IIPS, 1995, op. cit. (see reference 6).

10. Basu AM, Ignorance of family planning methods: an important constraint on use, Studies in Family Planning, 1984, 15(3):136-142.

11. Khan ME, Determinants of sterilization in India, in: Hermalin AI and Entwisle B, eds., The Role of Surveys in the Analysis of Family Planning Programs, Liège, Belgium: Ordina Publications, 1980, pp. 111-128.

12. Government of India, Family Welfare Program in India, Yearbook, 1990-1991, New Delhi: Ministry of Health and Family Welfare, Department of Family Welfare, 1991.

13. Pathak KB and Ram F, Pattern of population growth and redistribution in India, Demography India, 1991, 20(1):7-14; and Bhat PNM and Irudaya Rajan S, Demographic transition in Kerala revisited, Economic and Political Weekly, 1990, 25(35-36):1957-1980.

14. Population Research Centre (PRC) and IIIS, National Family Health Survey (MCH and Family Planning), Kerala, 1992-93, Thiruvananthapuram, India: PRC, University of Kerala; and Mumbai: IIPS, 1995; Pathak KB and Ram F, 1991, op. cit. (see reference 13); Bhat PNM and Irudaya Rajan S, 1990, op. cit. (see reference 13); Zachariah KC, Demographic transition: a response to official family planning programs, in: Zachariah KC and Irudaya Rajan S, eds., Kerala's Demographic Transition: Determinants and Consequences, 1997, New Delhi: Sage Publications, pp. 79-111.

15. Government of India, 1991, op. cit. (see reference 12). 16. IIPS, 1995, op. cit. (see reference 6).

17. Nair PS and Devi VS, Family Welfare Program in Kerala: Recent Patterns, 1992, PRC Report Series, Thiruvananthapuram, India: PRC, Vol. 92, No. 2.

18. Roy TK, Jayachandran V and Banarjee SK, Relationship between economic conditions and fertility in India; recent evidences from NFHS, Economic and Political Weekly, 1999, 34(42-43):3041-3046.

19. IIPS, 1995, op. cit. (see reference 6).

20. Vieira EM and Ford NJ, Regret after female sterilization among low-income women in São Paulo, Brazil, International Family Planning Perspectives, 1996, 22(1):32-37 \& 40; Zachariah KC, 1997, op. cit. (see reference 14); and Visaria P and Visaria L, Demographic transition; accelerating fertility decline in 1980s, Economic and Political Weekly, Special Issue, 1994, pp. 3281-3291.

21. Dharmalingam $A$, The social context of family planning in a South Indian village, International Family Planning Perspectives, 1995, 21(3):98-103; and Basu AM, 1984, op. cit. (see reference 10).

22. Zachariah KC, Models of development and demographic change, Demography India, 1998, 27(1):71-89.

23. Zachariah KC, 1997, op. cit. (see reference 14); and Visaria P and Visaria L, 1994, op. cit. (see reference 20).

24. Srinivasan K, An overview of demographic transition in India since 1970, in: Srinivasan K, ed., Population Policy and Reproductive Health, New Delhi: Hindustan Publishing, 1997, pp. 3-66.

\section{Zachariah KC, 1998, op. cit. (see reference 22).}

26. Mishra US and Irudaya Rajan S, Dynamics of age at maternity, in: Zachariah KC and Irudaya Rajan S, eds., 1997, op. cit. (see reference 14), pp. 205-211; and Nair SN, Determinants of birth intervals in Kerala: an application of Cox's hazard model, Genus, 1996, 52(3-4):47-65.

27. Visaria P and Visaria L, 1994, op. cit. (see reference 20). 28. Bhat PNM and Irudaya Rajan S, Demographic tran- sition since independence, in: Zachariah KC and Irudaya Rajan S, eds., 1997, op. cit. (see reference 14), pp. 33-78.

29. Ahmed MK, Sarkar AH and Rahman M, Determinants of induced abortion in rural Bangladesh, Demography India, 1996, 25(1): 105-118.

30. Basu AM, 1984, op. cit. (see reference 10).

31. Bhat PNM and Irudaya Rajan S, 1997, op. cit. (see reference 28).

32. Ramanathan M, Dilip TR and Padmadas SS, Quality of care in laproscopic sterilization camps: observations from Kerala, India, Reproductive Health Matters, 1995 , No. 6, pp. 84-93; Ravindran TK, Users' perspectives on fertility regulation methods, Economic and Political Weekly, 1993, 28(46-47):2508-2512; and Koenig MA, Foo GHC and Joshi K, Quality of Care Within the Indian Family Wel fare Program: A Review of Recent Evidence, Working Paper, Baltimore, MD, USA: Johns Hopkins Population Center, 1999, Series 99-01.

\section{Resumen}

Contexto: Muchas parejas de la India nunca han utilizado un método reversible para postergar o espaciar los nacimientos y recurren a la esterilización como su primer y único método. Se conoce muy poco sobre los factores que distinguen las parejas esterilizadas que utilizan métodos para espaciar los nacimientos y aquellas que recurren directamente a usar un método permanente.

Métodos: Se utilizaron datos de $2.029 \mathrm{mu}$ jeres, alguna vez casadas y que se encontraban protegidas por la esterilización, obtenidos de la Encuesta Nacional de Salud Familiar de la India de 1992-1993, realizada en el estado de Kerala. Se utilizaron técnicas de regresión logística de multivariables para evaluar las características socioeconómicas, demográficas $y$ de comportamiento que determinan el uso de un método temporal entre las parejas esterilizadas.

Resultados: Una vez controladas todas las variables significativas, un mayor nivel de educación (de ambos miembros de la pareja) aumenta independientemente la probabilidad de que una pareja protegida por la esterilización antes haya utilizado un método para postergar o espaciar los nacimientos, y lo mismo ocurre con las parejas de nivel socioeconómico mediano. Esta probabilidad también es significativamente más elevada entre las entrevistadas que habian experimentado un aborto, entre las mujeres cristianas y entre las que tenían más de 25 años de edad cuando ella (o cuando su marido) había sido esterilizado. Sin embargo, se redujo la probabilidad del uso de un método temporal entre las mujeres que preferían intervalos intergenésicos cortos y entre las mujeres de más edad (de 31 años y mayores). El intervalo intergenésico mediana entre el primer y segundo hijo de las parejas esterilizadas usuarias de un método reversible fue más prolongado que el que presentaban las parejas que habian recurrido solamente a la esterilización (32 meses contra 26 meses). 
Conclusiones: En Kerala, tanto el deseo de tener una familia poca numerosa como de acortar el período de exposición al riesgo de un embarazo pueden explicar la tendencia entre las parejas jóvenes de proceder directamente a la esterilización y nunca usar métodos reversibles. Un sistema que pone énfasis en la elección de métodos hecha por la clienta, y en los servicios de alta calidad que responden a las necesidades de las clientas, fomentarían aún más el uso de los métodos anticonceptivos para espaciar los nacimientos.

\section{Résumé}

Contexte: En Inde, de nombreux couples ne pratiquent jamais de méthode réversible apte à différer ou espacer leurs naissances; ils recourent plutôt à la stérilisation comme seule et unique méthode. Il existe peu de données sur les facteurs qui distinguent les couples stérilisés ayant eu recours aux méthodes d'espacement et ceux ayant directement choisi une méthode permanente.

Méthodes: Les données relatives à 2.029 femmes mariées protégées par la stérilisation ont été extraites de la partie de l'enquête nationale sur la santé de la famille (Indian $\mathrm{Na}$ tional Family Health Survey) menée en 1992-1993 dans l'état de Kerala. Les techniques de régression logistique multivariée sont utilisées pour évaluer les caractéristiques socioéconomiques, démographiques et com- portementales qui déterminent le recours antérieur à une méthode temporaire parmi les couples stérilisés.

Résultats: Après contrôle de toutes les variables significatives, l'accès à un niveau d'instruction plus élevé (par l'un ou l'autre des partenaires) accroît de manière indépendante la probabilité du recours antérieur à une méthode de recul ou d'espacement des naissances, de même qu'un rang socioénomique plus élevé. Cette probabilité se révèle également significativement supérieure parmi les répondants ayant vécu un avortement, parmi ceux stérilisés dans un établissement du secteur privé et parmi ceux âgés de plus de 25 ans au mo- ment de la stérilisation de l'un des partenaires. L'intervalle médian entre les premier et deuxième enfants nés de couples stérilisés qui avaient jamais pratiqué de méthode réversible était plus long qu'entre les enfants nés de couples passés directement à la stérilisation (32 par rapport à 26 mois).

Conclusions: Une campagne de sensibilisation de la population pourrait accroître en Inde la prévalence des méthodes temporaires et leur efficacité. Une approche axée sur le choix et l'offre de prestations dans le cadre de soins de haute qualité permettrait d'accroître davantage la pratique des méthodes d'espacement des naissances.

\section{Specialists in Reproductive Health}

Options is a leading provider of consultancy and management services in reproductive health. We have undertaken more than 400 assignments in over 40 countries in the developing world.



Our clients include: $\cdot$ national governments $\cdot$ the World Bank

- UNFPA $\cdot \mathrm{EC} \cdot \mathrm{DFID} \cdot \mathrm{GTZ} \cdot \mathrm{KfW}$ and non-profit organisations.

Visit our website for details of our current work and to order our new brochure.

www.options.co.uk Tel + 442073832494

\section{Acknowledgment to Reviewers}

The editors wish to express their appreciation to the following reviewers for their assistance during 1999 in evaluating material for International Family Planning Perspectives:

Carla AbouZahr

Agnès Adjamagbo

Sohail Agha

Abla Amawi

Mary P. Arends-Kuenning

Deborah Balk

Victoria A. Beard

J. Ties Boerma

Oona M. R. Campbell

John B. Casterline

Teresa Castro Martín

John G. Cleland

Barney Cohen

Alex Chika Ezeh

Samir M. Farid

Paul Feldblum

Anastasia J. Gage

Regina Görgen

David K. Guilkey
José Miguel Guzmán Molina

Cynthia C. Harper

Patrick Heuveline

Rick Homan

David R. Hotchkiss

Terence H. Hull

Tirbani Jagdeo

Barbara S. Janowitz

Eric R. Jensen

Brooke Ronald Johnson

Vasantha K. Kandiah

D. Lawrence Kincaid

Karungari Kiragu

John E. Knodel

Michael A. Koenig

Ulla M. Larsen

Michael T. Mbizvo

Gora Mboup

Mark E. McBride
James F. McCarthy

Dominique A. Meekers

Barbara S. Mensch

Vinod K. Mishra

Marc D. Mitchell

Thomas W. Pullum

Robert D. Retherford

Naomi Rutenberg

Shea O. Rutstein

Leslie Snyder

K. Srinivasan

Paul W. Stupp

Baffour K. Takyi

Turgay Ünalan

Thomas W. Valente

Julia Walsh

Cynthia Waszak

Ann A. Way 